\title{
Importance and Microbial Production of Gamma (Y)-Aminobutyric Acid (GABA) in Food Systems
}

\author{
Nilgün Özdemir ${ }^{*}$ \\ Ondokuz Mayis University, Faculty of Engineering, Departmant of Food Engineering, Samsun, Turkey, (ORCID: 0000-0002-4517-9214), nilgun.ozdemir@omu.edu.tr
}

(1st International Conference on Applied Engineering and Natural Sciences ICAENS 2021, November 1-3, 2021)

(DOI: $10.31590 /$ ejosat.1015283)

ATIF/REFERENCE: Özdemir, N. (2021). Importance and Microbial Production of Gamma (Y)-Aminobutyric Acid (GABA) in Food Systems. European Journal of Science and Technology, (28), 1330-1335.

\begin{abstract}
Gamma-aminobutyric acid (GABA) is a non-protein amino acid that is widely present in organisms. In particular, lactic acid bacteria (LAB) stand out in this regard. The biosynthesis of GABA in microorganisms is mainly regulated by $\mathrm{pH}$, which usually has the most pronounced effect on a fermentation process. Also, GABA production, affects media composition, fermentation time, and fermentation temperature. GABA has important positive functions on human health. In particular, it is known that GABA is effective in the development of neural diseases such as schizophrenia, alzheimer's disease, parkinson's disease, hormone regulation, and antihypertensive activity. In the present study, concepts related to GABA such as GABA-producing microorganisms, biosynthesis mechanism of GABA, and factors affecting GABA synthesis, and different approaches to increase GABA production and GABA content, especially in the food industry, will be emphasized.
\end{abstract}

Keywords: Gamma ( V)-aminobutyric acid, Bioactive Compound, Microbial Metabolites, Biosynthesis, Functional Microorganisms

\section{Gama (Y)-Aminobütirik Asitin (GABA) Gıda Sistemlerindeki Önemi ve Mikrobiyal Üretimi}

$\ddot{\mathbf{O z}}$

Gama-aminobütirik asit (GABA), organizmalarda yaygın olarak bulunan ve protein olmayan bir amino asittir. Özellikle laktik asit bakterileri (LAB) GABA üreticisi olarak öne çıkmaktadır. GABA'nın mikroorganizmalarda biyosentezinde en etkili faktör pH değeridir. Ayrıca, GABA üretimi ortam bileşimi fermantasyon süresi ve fermantasyon sıcaklığı etkiler. GABA'nın insan sağlığı üzerinde önemli pozitif etkileri vardır. Özellikle, GABA'nın şizofreni, alzheimer hastalığı, parkinson hastalığı, hormon regülasyonu ve antihipertansif aktivite gibi nöral hastalıkların gelişiminde etkili olduğu bilinmektedir. Bu çalışmada, GABA üreten mikroorganizmalar, GABA'nın biyosentez mekanizması ve GABA sentezini etkileyen faktörler gibi GABA ile ilgili kavramlar, özellikle gıda endüstrisinde GABA üretimi ve GABA içeriğinin artırılmasına yönelik farklı yaklaşımlar üzerinde durulacaktır.

Anahtar Kelimeler: Gama (Y)-aminobütirik asit, Biyoaktif Bileşik, Mikrobiyal Metabolitler, Biyosentez, Fonksiyonel Mikroorganizma

\footnotetext{
* Corresponding Author: nilgun.ozdemir@omu.edu.tr
} 


\section{Introduction}

GABA ( $\gamma$-aminobutyric acid) is a non-protein amino acid. It is produced from L-glutamic acid by glutamate decarboxylase enzyme (GAD) which is dependent on the cofactor pyridoxal-5'phosphate or vitamin B6 (Cui et al., 2020). It is known to widely present in microorganisms, plants, and animals. Although GABA has been widely studied in medical and pharmaceutical fields, Studies on its effect in the field of food have been very limited.
GABA is known to have multiple many functional features, such as neurotransmission, induction of hypotension, and diuretic and tranquiliser effects (Ribeiro et al., 2018). Besides, it has been beneficial in alcoholism treatment, depression and stimulation of immune cells (Diana et al., 2014).

The GABA content of most of the available GABAcontaining foods is not at a sufficient level for people to benefit from the functional effects of GABA. Therefore, the use of this

Table 1. Some GABA-producing microorganisms and their GABA production amounts (Cui et al., 2020)

\section{Lactic acid bacteria}

\begin{tabular}{l|r|r}
\hline \multicolumn{1}{c|}{ Microorganism } & GABA (g/L) & References \\
\hline Levilactobacillus brevis NCL912 & $\mathbf{2 0 5 . 8 0}$ & (Q. Wang et al., 2018) \\
\hline Lactobacillus buchneri WPZ001 & 129.00 & (Tamura et al., 2010) \\
\hline Enterococcus avium G-15 & 115.70 & (Zhao et al., 2015) \\
\hline Lactiplantibacillus plantarum CGMCC 1.2437 & 74.37 & (Seo et al., 2012) \\
\hline Latilactobacillus sakei B2-16 & 68.05 & (Wu et al., 2018) \\
\hline Levilactobacillus brevis RK03 & 62.52 & (Zhang et al., 2012) \\
\hline Levilactobacillus brevis TCCC13007 & 61.00 & (Binh et al., 2014) \\
\hline Levilactobacillus brevis K203 & 44.40 & (Wang et al., 2016) \\
\hline Enterococcus faecium GZ2 & 41.87 & (Li et al., 2010) \\
\hline Levilactobacillus brevis NCL912 & 35.66 & (Barrett et al., 2012) \\
\hline Levilactobacillus brevis DPC6108 & 32.32 & (Komatsuzaki et al., 2005) \\
\hline Lactobacillus paracasei NFRI 7415 & 31.14 & (Lin, 2013) \\
\hline Lactobacillus rhamnosus YS9 & 19.28 & (Chen et al., 2018) \\
\hline Streptococcus thermophilus fmb5 & 9.66 & (Ratanaburee et al., 2013) \\
\hline Pediococcus pentosaceus HN8 & 9.06 & (Kim et al., 2007) \\
\hline Weissella hellenica SB 105 & 7.69 & (Demirbaş et al., 2017) \\
\hline Leuconostoc citreum SC-10 & 0.50 & \\
\hline
\end{tabular}

The other microorganism

\begin{tabular}{l|r|r}
\hline \multicolumn{1}{c|}{ Microorganism } & GABA (g/L) & References \\
\hline Monascus purpureus & 7.45 & (J. J. Wang et al., 2003) \\
\hline Monascus sanguineus & 0.02 & (Dikshit \& Tallapragada, 2015) \\
\hline Pichia anomala MR-1 & 1.20 & (Masuda et al., 2008) \\
\hline Rhizopus microsporus var. oligosporus IFO 32002 & 17.40 & (Aoki et al., 2003) \\
\hline Rhizopus microsporus var. oligosporus IFO 32003 & 15.00 & (Aoki et al., 2003) \\
\hline
\end{tabular}

bioactive ingredient by the human body can be achieved, either as a nutraceutical product or through a new or modified functional food. The best, fastest, least costly way to do this is microbial biosynthesis. It is known that many microorganisms are able to synthesize GABA until now (Kook \& Cho, 2013; Li \& Cao, 2010).

In the present study, concepts related to GABA such as GABA-producing microorganisms, biosynthesis mechanism of GABA, and factors affecting GABA synthesis, and different approaches to increase GABA production and GABA content, especially in the food industry, will be emphasized.

\section{Gaba-Producing Microorganisms}

Microorganisms are an important source of GABA. It is known that many types of microorganisms have the ability to synthesize GABA, including yeast, fungi, and bacteria (Cui et al., 2020).

Among bacteria, there are several studies on the GABAproducing ability of especially lactic acid bacteria (LAB) (Tamura et al., 2010; Q. Wang et al., 2018). Since LAB has GRAS (generally regarded as safe) status, its use in foods as a GABA- producer or source of GABA is also prominent. Besides, GABA production capacity varies between different types of LAB. As far as is known, mainly, GABA producing LAB species can be specified as Levilactobacillus brevis, Lactobacillus buchneri, and Enterococcus avium according to high efficiency production (Park \& Oh, 2007; Tamura et al., 2010). Other LAB species (Pediococcus, Weissella, Streptococcus, Leuconostoc Pseudomesenteroides, Lacticaseibacillus, and Lactiplantibacillus etc.) and its production quantities are given in Table 1. According to the studies identified in the literature, Lactobacillus. brevis NCL912 isolated from Paocai, a type of Chinese pickle, is the strain with the highest yield with $205 \mathrm{~g} / \mathrm{L}$ GABA content when compared to other samples.

As for other microorganism types, their number is more limited (Table 1). For example, it was determined that. Monascu purpureus and Monascus sanguineus species of the nonpathogenic a fungus Monascus spp. produced 7.453 and $0.015 \mathrm{~g} / \mathrm{L}$ GABA, respectively, albeit in small quantities (Dikshit \& Tallapragada, 2015; J. J. Wang et al., 2003). Similarly, a yeast isolate that belong Pichia anomala, a marine yeast, were determined to produce high amount of GABA $(1.2 \mathrm{~g} / \mathrm{L})$ according to other yeast (Masuda et al., 2008). On the other hand, it was 
determined that two isolates that belong Rhizopus microspores var. oligosporus, a fungus, produced 17.40 and $15.00 \mathrm{~g} / \mathrm{L}$ GABA (Aoki et al., 2003). Despite all this information, the leading microorganisms in GABA production is LAB.

\section{Biosynthesis of GABA}

The biosynthesis of GABA by microorganisms is carried out by the glutamic acid decarboxylase (GAD) system. This system consists of GAD enzyme and glutamate/GABA antiporter GadC. This is shown in Figure 1.

Fistly, L-glutamat is transported a cell through the antiporter GadC. Subsequently, the decarboxylation of L-glutamate to GABA catalyzed by GAD. This leads to the formation of GABA and release of $\mathrm{CO} 2$ as by product. Finally, GABA is exported to the extracellular matrix by antiporter GadC. In this reaction, pyridoxal-5'-phosphate (PLP) (Vit B6) takes part as a cofactor.
GAD is an intracellular enzyme (Huang et al., 2007). The GAD enzyme is encoded by gad genes. Generally, LAB species have gadB gene (gadB2), but most Levilactobacillus brevis strains contain two distinct gad genes (gadA and gadB). However, Enterococcus avium 352 has three

gad genes (gadB1, gadB2 and gadB3) (Lyu et al., 2018; Yu et al., 2019). Besides, antiporter GadC transports GABA/Glu generally under acidic conditions (Kook \& Cho, 2013). Furthermore GADs from LAB are specific for L-glutamic acid.

Interestingly, although the gad gene is found, some LAB strains cannot produce GABA. In one study (Nomura et al., 2000), this situation was examined. It was determined that a LAB strain (Lactococcus cremoris) that had the Gad gene, but did not produce GABA had a mutation in the Gad gene. This mutation was determined to be a one-base deletion of adenine and a onebase insertion of thymine were detected. This indicated that the application of polymerase chain reaction (PCR)-based methods for the detection of GABA-producing $L A B$ is quite difficult.

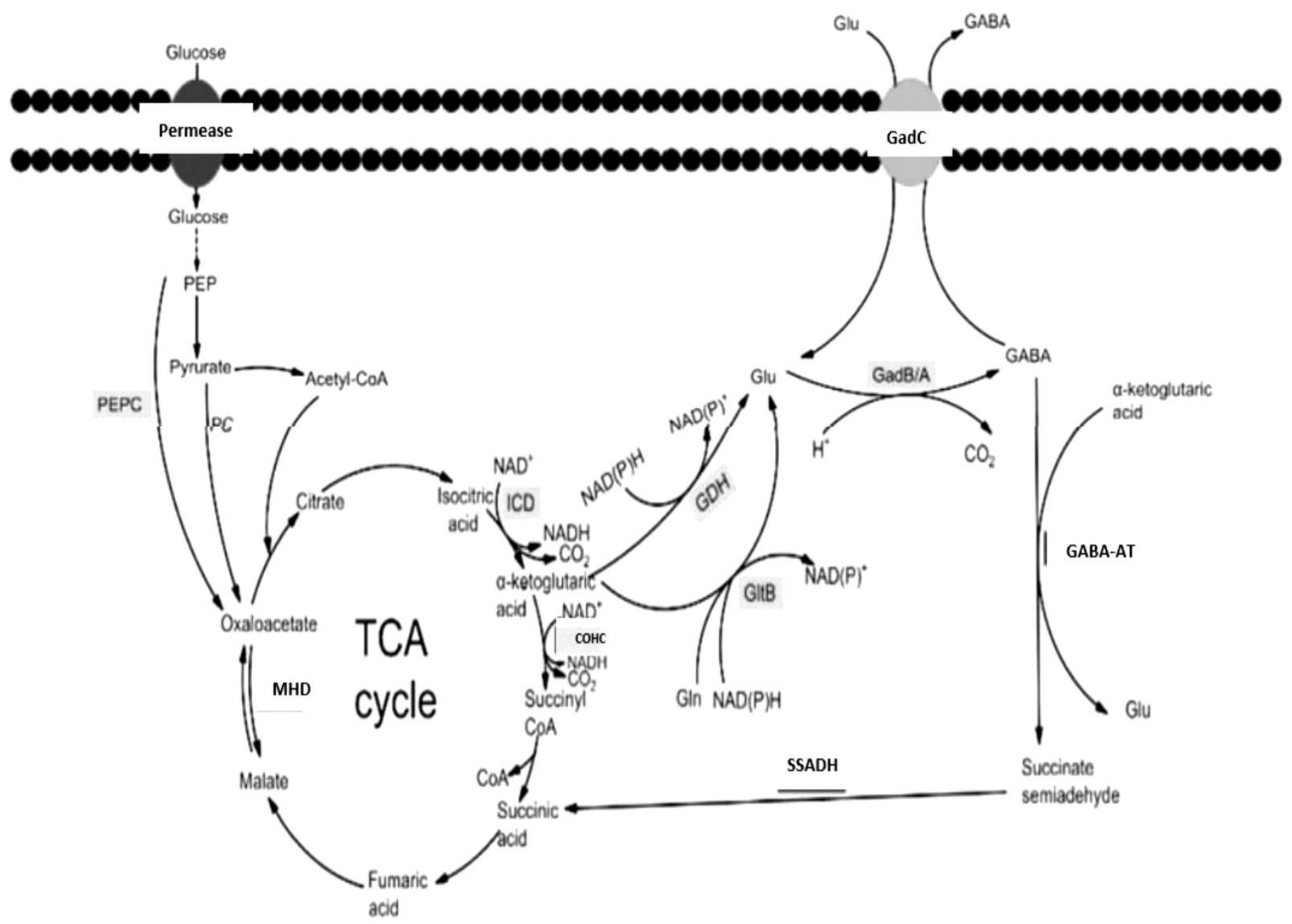

Figure 1 The biosynthetic pathway of GABA by microbes (Kook \& Cho, 2013; Cui et al., 2020)

\section{Factors Affecting GABA Synthesis}

Different fermentation factors affect the rate of GABA production by microorganisms. The $\mathrm{pH}$ value of media, 
temperature of media, cultivation time and media additives are among the prominent factors.

\section{1. $\quad$ pH value}

Since the biochemical properties of GAD differ between different microorganisms, the effective $\mathrm{pH}$ value for maximum GABA production depends on the species (Dhakal et al., 2012). Generally, in studies (Komatsuzaki et al., 2005; Siragusa et al., 2007; Choi et al., 2012)Optimum pH values were determined as acidic values and values below $\mathrm{pH} 6.5$.

Furthermore, the production of GABA is not only dependent on activating the activities of GAD but also on inhibiting the activities of GABA-decomposing enzymes. GABA can be converted to the succinic semi-aldehyde and subsequently to succinate. The enzymes played role in these reactions; have optimum pH value around 8-8.5 (Dhakal et al., 2012). Therefore, a value that can inhibit these enzymes in the fermentation medium and is also suitable for GAD activity is important.

\subsection{Temperatures}

The incubation temperature is important for GABA production. In general, a high GABA yield was obtained in the fermentation temperature range from $25^{\circ} \mathrm{C}$ to $40^{\circ} \mathrm{C}$. For example, L. plantarum DSM19463 synthesized the highest amount of GABA at temperatures between $30^{\circ} \mathrm{C}$ and $35^{\circ} \mathrm{C}$ (Di Cagno et al., 2010). The optimum temperatures for some L. brevis strains were found to be as $30^{\circ} \mathrm{C}, 37^{\circ} \mathrm{C}$, and $40^{\circ} \mathrm{C}$, respectively (Huang et al., 2007; Ueno, 2000).

\subsection{Fermentation Time}

The time factor plays an important role in the fermentation. In a study (Di Cagno et al., 2010), L plantarum DSM19463 required $72 \mathrm{~h}$ of fermentation time to reach the highest production of GABA, respectively. In another study (Kim et al., 2009), L. brevis GABA-100 reached the highest level of GABA at the 12 th day. On the other hand, in a study in which a co-factor was added to the medium (Yang et al., 2008), it was determined that the higher amount of GABA was produced at $48 \mathrm{~h}$.

\subsection{Effect of Media Composition}

Nutrient composition affect the GABA production by fermentation. For this, PLP (vit B6) as the coenzymes of GAD are the major factors (Komatsuzaki et al., 2005).

On the other hand, the concentrations and diversity of substrates are important for GABA yield. In particular, a nitrogen source is needed. Because l-glutamate is needed for GABA production. This amino acid must either be added to the medium from the outside, or the nutrients necessary for microorganisms capable of synthesizing this amino acid must be given to the medium.

L-glutamate is formed by the conversion of $\alpha$-ketoglutarate by 1-glutamate dehydrogenase. Alpha-ketoglutarate is $\mathrm{s}$ synthesized from glucose via the glycolysis pathway and part of the tricarboxylic acid (TCA) cycle. Furthermore, it was known that the addition of sulfate ions increased the GAD activity (Dhakal et al., 2012).

\section{Effect of GABA on Health}

GABA as an effective compound with bio-functions can be used as a drug with significant pharmacological effects. Besides, e-ISSN: 2148-2683 it is effective as a component of health food as well (DiezGutiérrez et al., 2020).

GABA is an inhibitory neuro-transmitter. Neurotransmitters are small chemical conductors that enable the flow of information in nerve cells. Because of this feature, it is known that GABA can modulate mood (e.g. relaxation), sleep disorders, and temporal and spatial memory. Also, several studies have demonstrated the importance of GABA in the development of neural diseases such as schizophrenia, Alzheimer's disease, Parkinson's disease (Boonstra et al., 2015; Porges et al., 2017).

On the other hand, GABA has cardiovascular effect. Because GABA has the effect of reducing hypertension (Abd El-Fattah et al., 2018). Another effect of GABA is hormone regulator. It regulates progesterone, thyroid, and insulin hormones (Adeghate \& Ponery, 2001; Wiens \& Trudeau, 2006).

Furthermore, GABA has serum cholesterol-lowering effect (Ngo \& Vo, 2019), control effect in asthma (Arnold et al., 2016). Some studies have shown that it also has an effect on cancer cells such as Delaying and/or inhibiting the proliferation of cancer cells and potent tumour suppression (Brzozowska et al., 2017; Wang et al., 2016).

\section{Conclusion and Future Prospects}

The GABA-producing ability could be of interest for the food industry. GABA has been evidenced as a powerful bioactive compound with numerous health-beneficial effects. Thus, the functional foods produced from GABA are believed to be able to prevent and/or treat different diseases, especially hypertension, diabetes, and neurological disorders. Whereby, the researches into large-scale production, biotechnological techniques, and high Gaba-producing strains will be increased in food industry.

\section{Acknowledge}

The authors declare no conflict of interest. This research was not funded by any organization. Also, abstract of this study was presented at congress " 1 st International Conference on Applied Engineering and Natural Sciences ICAENS 2021, November 1-3, 2021 (Konya / Turkey)."

\section{References}

Abd El-Fattah, A., Sakr, S., El-Dieb, S., \& Elkashef, H. (2018). Developing functional yogurt rich in bioactive peptides and gamma-aminobutyric acid related to cardiovascular health. LWT, 98, 390-397. https://doi.org/10.1016/j.lwt.2018.09.022

Adeghate, E., \& Ponery, A. S. (2001). GABA in the endocrine pancreas cellular localization and the function $i$ normal and diabetic rats. https://doi.org/10.1054/tice.2001.0217

Aoki, H., Uda, I., Tagami, K., Furuya, Y., Endo, Y., \& Fujimoto, K. (2003). The Production of a New Tempeh-like Fermented Soybean Containing a High Level of g-Aminobutyric Acid by Anaerobic Incubation with Rhizopus. In Biosci. Biotechnol. Biochem (Vol. 67, Issue 5).

Arnold, L. A., Forkuo, G. S., Nieman, A. N., Yu, O. B., Guthrie, M. L., Yuan, N. Y., Kodali, R., Jahan, R., Emala, C. W., Cook, J. M., Stafford, D. C., Grayson, M. H., Kamekura, R., Kawata, K., Jitsukawa, S., Nagaya, T., Yamashita, K., Ito, F., Takano, K., ... Wray, B. B. (2016). L13 A New Pharmacological Approach for Asthma through Tissue-Specific Modulation of the GABA(A) Receptor L15 Case Report of a Previously 
Unreported Type of DOCK8 Deficiency Abstracts AB393. In $J$ Allergy Clin Immunol (Vol. 137, Issue 2).

Barrett, E., Ross, R. P., O'Toole, P. W., Fitzgerald, G. F., \& Stanton, C. (2012). $\gamma$-Aminobutyric acid production by culturable bacteria from the human intestine. Journal of Applied Microbiology, 113(2), 411-417. https://doi.org/10.1111/j.1365-2672.2012.05344.x

Binh, T. T. T., Ju, W. T., Jung, W. J., \& Park, R. D. (2014). Optimization of $\gamma$-amino butyric acid production in a newly isolated Lactobacillus brevis. Biotechnology Letters, 36(1), 93-98. https://doi.org/10.1007/s10529-013-1326-z

Boonstra, E., de Kleijn, R., Colzato, L. S., Alkemade, A., Forstmann, B. U., \& Nieuwenhuis, S. (2015). Neurotransmitters as food supplements: The effects of GABA on brain and behavior. In Frontiers in Psychology (Vol. 6, Issue OCT). Frontiers Research Foundation. https://doi.org/10.3389/fpsyg.2015.01520

Brzozowska, A., Burdan, F., Duma, D., Solski, J., \& Mazurkiewicz, M. (2017). $\gamma$-amino butyric acid (GABA) level as an overall survival risk factor in breast cancer. Annals of Agricultural and Environmental Medicine, 24(3), 435-439. https://doi.org/10.26444/aaem/75891

Chen, L., Alcazar, J., Yang, T., Lu, Z., \& Lu, Y. (2018). Optimized cultural conditions of functional yogurt for $\gamma$-aminobutyric acid augmentation using response surface methodology. Journal of Dairy Science, 101(12), 10685-10693. https://doi.org/10.3168/jds.2018-15391

Cui, Y., Miao, K., Niyaphorn, S., \& Qu, X. (2020). Production of gamma-aminobutyric acid from lactic acid bacteria: A systematic review. International Journal of Molecular Sciences, 21(3), 1-21. https://doi.org/10.3390/ijms21030995

Demirbaş, F., İspirli, H., Kurnaz, A. A., Yilmaz, M. T., \& Dertli, E. (2017). Antimicrobial and functional properties of lactic acid bacteria isolated from sourdoughs. LWT - Food Science and Technology, 79, 361-366. https://doi.org/10.1016/j.lwt.2017.01.067

Dhakal, R., Bajpai, V. K., \& Baek, K.-H. (2012). PRODUCTION OF GABA ( $\gamma$-AMINOBUTYRIC ACID) BY MICROORGANISMS: A REVIEW. Brazilian Journal of Microbiology, 1230-1241.

Di Cagno, R., Mazzacane, F., Rizzello, C. G., De Angelis, M., Giuliani, G., Meloni, M., De Servi, B., \& Gobbetti, M. (2010). Synthesis of $\gamma$-aminobutyric acid (GABA) by Lactobacillus plantarum DSM19463: Functional grape must beverage and dermatological applications. Applied Microbiology and Biotechnology, 86(2), 731-741. https://doi.org/10.1007/s00253-009-2370-4

Diana, M., Tres, A., Quílez, J., Llombart, M., \& Rafecas, M. (2014). Spanish cheese screening and selection of lactic acid bacteria with high gamma-aminobutyric acid production. $L W T$ - Food Science and Technology, 56(2), 351-355. https://doi.org/10.1016/J.LWT.2013.11.027

Diez-Gutiérrez, L., San Vicente, L., Luis, L. J., Villarán, M. del C., \& Chávarri, M. (2020). Gamma-aminobutyric acid and probiotics: Multiple health benefits and their future in the global functional food and nutraceuticals market. In Journal of Functional Foods (Vol. 64). Elsevier Ltd. https://doi.org/10.1016/j.jff.2019.103669

Dikshit, R., \& Tallapragada, P. (2015). Screening and optimization of $\gamma$-aminobutyric acid production from Monascus sanguineus under solid-state fermentation. Frontiers in Life Science, 8(2), 172-181. https://doi.org/10.1080/21553769.2015.1028654
Huang, J., Mei, L. H., Wu, H., \& Lin, D. Q. (2007). Biosynthesis of $\gamma$-aminobutyric acid (GABA) using immobilized whole cells of Lactobacillus brevis. World Journal of Microbiology and Biotechnology, 23(6), 865-871. https://doi.org/10.1007/s11274-006-9311-5

Kim, J. Y., Lee, M. Y., Ji, G. E., Lee, Y. S., \& Hwang, K. T. (2009). Production of $\gamma$-aminobutyric acid in black raspberry juice during fermentation by Lactobacillus brevis GABA100. International Journal of Food Microbiology, 130(1), 12-16. https://doi.org/10.1016/j.ijfoodmicro.2008.12.028

Komatsuzaki, N., Shima, J., Kawamoto, S., Momose, H., \& Kimura, T. (2005). Production of $\gamma$-aminobutyric acid (GABA) by Lactobacillus paracasei isolated from traditional fermented foods. Food Microbiology, 22(6), 497-504. https://doi.org/10.1016/j.fm.2005.01.002

Kook, M. C., \& Cho, S. C. (2013). Production of GABA (gamma amino butyric acid) by lactic acid bacteria. Korean Journal for Food Science of Animal Resources, 33(3), 377-389. https://doi.org/10.5851/kosfa.2013.33.3.377

Li, H., \& Cao, Y. (2010). Lactic acid bacterial cell factories for gamma-aminobutyric acid. In Amino Acids (Vol. 39, Issue 5, pp. 1107-1116). https://doi.org/10.1007/s00726-010-0582-7

Li, H., Qiu, T., Huang, G., \& Cao, Y. (2010). Production of gamma-aminobutyric acid by Lactobacillus brevis NCL912 using fed-batch fermentation. Microbial Cell Factories, 9. https://doi.org/10.1186/1475-2859-9-85

Lin, Q. (2013). Submerged fermentation of Lactobacillus rhamnosus YS9 for g-aminobutyric acid (GABA) production. www.sbmicrobiologia.org.br

Lyu, C., Zhao, W., Peng, C., Hu, S., Fang, H., Hua, Y., Yao, S., Huang, J., \& Mei, L. (2018). Exploring the contributions of two glutamate decarboxylase isozymes in Lactobacillus brevis to acid resistance and $\gamma$-aminobutyric acid production. Microbial Cell Factories, 17(1). https://doi.org/10.1186/s12934-018-1029-1

Masuda, K., Guo, X. F., Uryu, N., Hagiwara, T., \& Watabe, S. (2008). Isolation of marine yeasts collected from the pacific ocean showing a high production of $\gamma$-aminobutyric acid. Bioscience, Biotechnology and Biochemistry, 72(12), 32653272. https://doi.org/10.1271/bbb.80544

Ngo, D. H., \& Vo, T. S. (2019). An updated review on pharmaceutical properties of gamma-aminobutyric acid. In Molecules (Vol. 24, Issue 15). MDPI AG. https://doi.org/10.3390/molecules24152678

Nomura, M., Kobayashi, M., Ohmomo, S., \& Okamoto, T. (2000). Inactivation of the Glutamate Decarboxylase Gene in Lactococcus lactis subsp. cremoris. In APPLIED AND Environmental Microbiology (Vol. 66, Issue 5). https://journals.asm.org/journal/aem

Park, K. B., \& Oh, S. H. (2007). Cloning, sequencing and expression of a novel glutamate decarboxylase gene from a newly isolated lactic acid bacterium, Lactobacillus brevis OPK-3. Bioresource Technology, 98(2), 312-319. https://doi.org/10.1016/J.BIORTECH.2006.01.004

Kim, S. H, Shin, B. H., Kim, Y. H, \& Jeon, S. J. (2007). Cloning and Expression of a Full-Length Glutamate Decarboxylase Gene from Lactobacillus brevis BH2. In Biotechnology and Bioprocess Engineering (Vol. 12).

Porges, E. C., Woods, A. J., Lamb, D. G., Williamson, J. B., Cohen, R. A., Edden, R. A. E., \& Harris, A. D. (2017). Impact of tissue correction strategy on GABA-edited MRS findings. NeuroImage, 162, 249-256. https://doi.org/10.1016/j.neuroimage.2017.08.073 
Ratanaburee, A., Kantachote, D., Charernjiratrakul, W., \& Sukhoom, A. (2013). Selection of $\gamma$-aminobutyric acidproducing lactic acid bacteria and their potential as probiotics for use as starter cultures in Thai fermented sausages (Nham). International Journal of Food Science and Technology, 48(7), 1371-1382. https://doi.org/10.1111/ijfs.12098

Ribeiro, S. C., Domingos-Lopes, M. F. P., Stanton, C., Ross, R. P., \& Silva, C. C. G. (2018). Production of Y-aminobutyric acid (GABA) by Lactobacillus otakiensis and other Lactobacillus sp. isolated from traditional Pico cheese. International Journal of Dairy Technology, 71(4), 1012-1017. https://doi.org/10.1111/1471-0307.12527

Seo, Y. C., Choi, W. Y., Kim, J. S., Lee, C. G., Ahn, J. H., Cho, H. Y., Lee, S. H., Cho, J. S., Joo, S. J., \& Lee, H. Y. (2012). Enhancement of the Cognitive Effects of $\gamma$-Aminobutyric Acid from Monosodium Glutamate Fermentation by Lactobacillus sakei B2-16. Food Biotechnology, 26(1), 29-44. https://doi.org/10.1080/08905436.2011.645937

Siragusa, S., De Angelis, M., Di Cagno, R., Rizzello, C. G., Coda, R., \& Gobbetti, M. (2007). Synthesis of $\gamma$-aminobutyric acid by lactic acid bacteria isolated from a variety of Italian cheeses. Applied and Environmental Microbiology, 73(22), 7283-7290. https://doi.org/10.1128/AEM.01064-07

Tamura, T., Noda, M., Ozaki, M., Maruyama, M., Matoba, Y., Kumagai, T., \& Sugiyama, M. (2010). Establishment of an Efficient Fermentation System of Gamma-Aminobutyric Acid by a Lactic Acid Bacterium, \&lt;i\&gt;Enterococcus avium\&lt;/igt; G-15, Isolated from Carrot Leaves. Biological \& Pharmaceutical Bulletin, 33(10), 1673-1679. https://doi.org/10.1248/bpb.33.1673

Ueno, H. (2000). Enzymatic and structural aspects on glutamate decarboxylase. In Journal of Molecular Catalysis B: Enzymatic (Vol. 10). www.elsevier.comrlocatermolcatb

Wang, C., Zhu, C. L., Huang, Z. J., Wang, G., Huang, Q., Liu, C. H., \& Wang, W. (2016). $\gamma$-aminobutyric acid inhibits the growth of cholangiocarcinoma via cAMP/PKA signal pathway. International Journal of Clinical and Experimental Medicine, 9(6), 9992-9998.

Wang, J. J., Lee, C. L., \& Pan, T. M. (2003). Improvement of monacolin $\mathrm{K}, \gamma$-aminobutyric acid and citrinin production ratio as a function of environmental conditions of Monascus purpureu s NTU 601. Journal of Industrial Microbiology and Biotechnology, 30(11), 669-676. https://doi.org/10.1007/s10295-003-0097-2

Wang, Q., Liu, X., Fu, J., Wang, S., Chen, Y., Chang, K., \& Li, H. (2018). Substrate sustained release-based high efficacy biosynthesis of GABA by Lactobacillus brevis NCL912. Microbial Cell Factories, 17(1). https://doi.org/10.1186/s12934-018-0919-6

Wiens, S. C., \& Trudeau, V. L. (2006). Thyroid hormone and $\gamma$ aminobutyric acid (GABA) interactions in neuroendocrine systems. In Comparative Biochemistry and Physiology - A Molecular and Integrative Physiology (Vol. 144, Issue 3, pp. 332-344). Elsevier Inc. https://doi.org/10.1016/j.cbpa.2006.01.033

Wu, C. H., Hsueh, Y. H., Kuo, J. M., \& Liu, S. J. (2018). Characterization of a potential probiotic lactobacillus brevis RK03 and efficient production of $\gamma$-aminobutyric acid in batch fermentation. International Journal of Molecular Sciences, 19(1). https://doi.org/10.3390/ijms19010143

Yang, S. Y., Lü, F. X., Lu, Z. X., Bie, X. M., Jiao, Y., Sun, L. J., \& $\mathrm{Yu}$, B. (2008). Production of $\gamma$-aminobutyric acid by Streptococcus salivarius subsp. thermophilus Y2 under submerged fermentation. Amino Acids, 34(3), 473-478. https://doi.org/10.1007/s00726-007-0544-X

Yu, T., Li, L., Zhao, Q., Wang, P., \& Zuo, X. (2019). Complete genome sequence of bile-isolated Enterococcus avium strain 352. Gut Pathogens, 11(1). https://doi.org/10.1186/s13099019-0294-9

Zhang, Y., Song, L., Gao, Q., Yu, S. M., Li, L., \& Gao, N. F. (2012). The two-step biotransformation of monosodium glutamate to GABA by Lactobacillus brevis growing and resting cells. Applied Microbiology and Biotechnology, 94(6), 1619-1627. https://doi.org/10.1007/s00253-012-3868-8

Zhao, A., Hu, X., Pan, L., \& Wang, X. (2015). Isolation and characterization of a gamma-aminobutyric acid producing strain Lactobacillus buchneri WPZ001 that could efficiently utilize xylose and corncob hydrolysate. Applied Microbiology and Biotechnology, 99(7), 3191-3200. https://doi.org/10.1007/s00253-014-6294-2

Zhuang, K., Jiang, Y., Feng, X., Li, L., Dang, F., Zhang, W., \& Man, C. (2018). Transcriptomic response to GABA-producing Lactobacillus plantarum CGMCC $1.2437 \mathrm{~T}$ induced by LMSG. PLoS ONE, 13(6). https://doi.org/10.1371/journal.pone.0199021 